\title{
Physical and mechanical properties of rubberwood (Hevea brasiliensis) dyed with Lasiodiplodia theobromae
}

\author{
Boshi Zhao, Zhiming Yu*, Yang Zhang and Chusheng Qi
}

\begin{abstract}
Blue staining on rubberwood (Hevea brasiliensis) is a common kind of defect. There currently exists much research focused on the prevention and control of blue staining. However, little research has been concentrated on the utilization of blue staining for green dyeing. The research conveyed in this paper primarily used Lasiodiplodia theobromae to dye rubberwood, and used scanning electron microscope (SEM), energy-dispersive spectrometer (EDS), X-ray diffraction (XRD), and fourier transform infrared spectrometer (FTIR) to analyze the commission internationale eclairage (CIE) $L^{*} a^{*} b^{*}$ value of color, the contact angle, the $\mathrm{pH}$ value, 24-h water absorption, mass loss ratio, and compressive strength in increments between 5 and 40 days. The results found that the color of rubberwood became darker and more uniform, and that the surface dyed with fungi can reach a super-hydrophobic state. With the increase of time, the $\mathrm{pH}$ value of rubberwood changed from acidic to alkaline. Furthermore, hyphae entered the wood mainly through vessels for their large pore diameter, and reduced water absorption. Mass loss ratio increased gradually between 5 and 40 days. The research in this paper concludes that the microorganism was an effective method of wood dyeing, and lays a foundation for further research.
\end{abstract}

Keywords: Wood dyeing, Wood preservation, Lasiodiplodia theobromae, Rubberwood

\section{Introduction}

Coloring of wood is a significant processing technology that can improve surface decoration properties and reduce wood defects, thereby increasing the value of wood [1]. Currently, wood staining primarily depends on physical, chemical and biological methods. Physical method such as thermal modification mainly uses high temperature to induce discoloration. In this process, there also exist chemical changes, for thermal modification can change the content and structure of wood chemical composition, such as cellulose, hemicellulose, lignin, and extractives [2-4]. However, thermal modification requires significant electrical and thermal energy [5]. The chemical dyeing method mainly uses chemical agents such as chitosan, metal, and pigment dyes to dip or brush the wood, and the dyes either cover the wood surface or

*Correspondence: yuzhiming@bjfu.edu.cn

MOE Key Laboratory of Wooden Material Science and Application, Beijing Forestry University, Beijing 100083, China enter into the wood cell to change the wood color; however, chemical dyes still have problems with colorfastness, water-fastness, and so on [6-8]. Furthermore, the chemical method may be harmful to the environment and to human health [9]. Biological method usually utilizes stains to change the color of wood, such as extractives in trees and pigment in microorganism, and that is an effective way on wood staining $[10,11]$.

Biotechnology is a possible solution for wood processing, and microorganisms have the potential to dye wood. Above all, microorganisms have a close relationship with wood because both are living organisms, and there are many kinds of fungi that live in wood [12]. With the appropriate temperature, humidity, light, and $\mathrm{pH}$, microorganisms can live in wood and change the wood into a variety of colors. However, these discolorations have mostly been regarded as defects of wood [13, 14]. Researchers have proposed a variety of methods to prevent against the discoloration [15-17]. Wood discoloration is usually caused by decaying fungi, mold, and stain fungi $[18,19]$. Mold is unsuitable for 
utilization in wood dyeing as it is unsafety for human and uncontrollability [20]. Decaying fungi have been investigated for its application for wood decoration, such as in the case of spalting wood [21]. Spalting wood is formed by the metabolic processes of fungi, whereby fungi produce zone lines and pigment inside the wood [22]. In recent years, research on spalting wood mainly concentrated on the screening of fungi, the extraction of pigment, the properties of spalted wood, and production design. The relevant results have indicated that fungal pigments have superior colorfastness and decorative performance [23-29]. However, decaying fungi decreased the mechanical properties of wood [30]. Compared with decaying fungi, stain fungi do not cause an obvious reduction of mechanical properties [31]. Therefore, stain fungi may have more potential for wood dyeing.

Blue-stained wood is the most prevalent phenomenon in wood stain, and it often takes place on all kinds of wood, and rubberwood (Hevea brasiliensis) is prone to be infested by blue staining fungus. Rubberwood is a tropical hardwood species mainly distributed in countries such as China, Indonesia, Malaysia, Thailand, and India [32]. Rubberwood can be used to make wood-based panels, furniture, and joinery products, but rubberwood is also prone to attack by stain fungi in green and dry conditions. The stain reduces the decorative value of wood, and causes financial losses not only in Southeast Asia, but also in the wood industry worldwide [33, 34]. Much research has classified the blue stain fungi, and some methods have been proposed to prevent wood stain. The results have indicated that the most popular stain fungus is Lasiodiplodia theobromae, which can seriously attack rubberwood in less than 3 days [35-39]. Additional results have shown that the mechanical properties of stained wood not only did not obviously diminish, but also were slightly enhanced [3942]. In recent years, several papers paid attention on the decoration of wood dyed with blue stains $[11,26,41]$. This paper mainly studied the relationship between $L$. theobromae and rubberwood, sought the path that how the fungi enter the rubberwood, analyzed the degradation of fungi on wood component, and physical and mechanical properties. The purpose was to learn about the mechanism of fungi and rubberwood, control the movement of fungi in rubberwood, and increase the decoration of rubberwood. The final purpose was to control decorative pattern on wood surface in further research.

\section{Materials and methods Materials}

\section{Wood and fungi species selection}

Lasiodiplodia theobromae is the most popular stain fungi, and rubberwood is easily infested by it; so this paper chose them as experimental material. The rubberwood was provided by Hainan State Farms Forest Industrial Group Co., Ltd. The diameter of the rubberwood was about $20 \mathrm{~cm}$ in radial direction, and the wood was cut to the size of $20 \times 20 \times 20 \mathrm{~mm}$ for further use. $L$. theobromae (Pat.) Griffon \& Maubl (cfcc 87131) was provided by the China Forestry Culture Collection Center, and which was extracted from the popular wood in the Siyang, Jiangsu province. According to the Regulations on Biosafety Management of Pathogenic Microorganism Laboratories in China [43], L. theobromae (Pat.) Griffon \& Maubl belongs to the fourth type of pathogenic microorganisms, which have been proven to be safe to human. L. theobromae (Pat.) Griffon \& Maubl was generally cultivated into a potato dextrose agar culture medium (PDA) that was obtained from Beijing Aoboxing Biology Technology Co., Ltd.

\section{Expand incubation and inoculation procedure}

Lasiodiplodia theobromae (Pat.) placed in PDA slant culture medium were largely cultivated in plain culture medium. The culture dishes were conditioned at $(28 \pm 1){ }^{\circ} \mathrm{C}$ and $(80 \pm 5) \%$ relative humidity $(\mathrm{RH})$ for 3 days, and hyphae filled with culture dishes.

The steps above were repeated, and the hole puncher was used to make the medium grow for 3 days into the fungi cake, the diameter of which was $5 \mathrm{~mm}$, and then the fungi cake was brought to the middle surface of the medium. The culture dishes were conditioned at $(28 \pm 1)^{\circ} \mathrm{C}$ and $(80 \pm 5) \% \mathrm{RH}$ for 7 days. The fungi grew in the culture dish in 3 days, and secreted the pigment over the culture dish in 7 days.

The rubberwood was sterilized in autoclave under $0.1 \mathrm{MPa}$ and $121{ }^{\circ} \mathrm{C}$ for $30 \mathrm{~min}$, and then put into a constant temperature humidity chamber for 7 days, which made the moisture content of wood about $12 \%$, and the specific gravity about $0.6-0.65$. Next, the wood was placed on the culture in the grain direction. In addition, the wood was cultivated at $(28 \pm 1){ }^{\circ} \mathrm{C}$ and $(80 \pm 5) \% \mathrm{RH}$ for $0,5,10,20,30$, and 40 days, respectively, for the fungi can make the properties of rubberwood change with time increasing. What is more, the number of woods was sufficient, because the number of specimens for most tests in 2.2 was at least 5 times.

\section{Characterization \\ Scanning electron microscopy (SEM)}

A Gemini SEM 300 made in Germany was used to analyze the distribution of hyphae in wood cells, and the samples were studied under energy-dispersive spectrometer (EDS) analysis to determine the element content of wood. EDS can analysis the element content of sample surface. Before the above steps were taken, the samples were cut into cubes less than $10 \mathrm{~mm}$ on each side, and 
then the top surfaces were coated with gold. The magnification was set from 150 to 500 times enlargement.

\section{$X$-ray diffraction (XRD) analysis}

The relative crystallinity was investigated by an XRD analyzer (Burker D8 ADVANCE, Germany) at $40 \mathrm{kV}$ and $40 \mathrm{~mA}$ at a rate of $4 \% \mathrm{~min}$. The scanning range was from 5 to $45^{\circ}$. All of the samples were ground into powder using a 200-mesh griddle. The crystallinity index (CI) for rubberwood was determined by the following equation [44]. Each sample was repeated for 3 times.

$$
\mathrm{CI}=\frac{I_{002}-I_{\mathrm{am}}}{I_{002}} \times 100[\%],
$$

where $I_{002}$ represents the maximum value of bands at $22.5^{\circ}$, and $I_{\mathrm{am}}$ represents the minimum value of bands at $18.5^{\circ}$.

\section{Fourier transform infrared spectroscopy (FTIR) characterization}

FTIR spectra at 0 and 40 days of rubberwood (200 mesh powder) were analyzed with a Nicolet 6700 made in the USA, and with a resolution of $4 \mathrm{~cm}^{-1}$ from 400 to $4000 \mathrm{~cm}^{-1}$. The purpose of this analysis was to observe the differences between the chemical bonds by examining the band values.

\section{Measurement of dyed wood color}

The effect of fungi on rubberwood color was analyzed with a NH310 portable colorimeter from Shenzhen 3nh Technology Co., Ltd. $L^{*}$ (lightness and darkness), $a^{*}$ (redness and greenness), and $b^{*}$ (yellowness and blueness) were the color parameters. At first, the colorimeter needs to read the primary $L_{0}{ }^{*}, a_{0}{ }^{*}$, and $b_{0}{ }^{*}$ values of the untreated wood, and then measure the $\Delta L^{*}, \Delta a^{*}, \Delta b^{*}$, and $\Delta E^{*}$ values of rubberwood from 5 to 40 days. $\Delta E^{*}$ represents the total color difference, and each parameter is the average value of five times.

Color change of rubberwood dyed with fungi was analyzed with a one-way analysis of variance (ANOVA) followed by a Tukey's honestly significant difference (Turkey HSD) test run on statistical product and service solutions (SPSS) version 18.0 , which mainly analyzed the relationship between time and color change.

$\Delta L^{*}, \Delta a^{*}, \Delta b^{*}$, and $\Delta E^{*}$ were calculated according to the following equation, and the subscript $n$ in Eqs. (2)(4) represents the different days from 0 to 40 days.

$$
\begin{aligned}
& \Delta L^{*}=L_{n}{ }^{*}-L_{0}{ }^{*} . \\
& \Delta a^{*}=a_{n}{ }^{*}-a_{0}{ }^{*} \\
& \Delta b^{*}=b_{n}{ }^{*}-b_{0}{ }^{*}
\end{aligned}
$$

$$
\Delta E^{*}=\left(\Delta L^{* 2}+\Delta a^{* 2}+\Delta b^{* 2}\right)^{1 / 2}
$$

\section{Measurement of contact angle}

The contact angle was measured by a Contact Angle System Optical Contact Angle (DataPhysics, Germany), with time set between 0 and $16 \mathrm{~s}$, and the amount of a drop of water was $3 \mu \mathrm{L}$ which contacted on cross section. The measurement of each sample was repeated at least 5 times.

\section{Wood $\mathrm{pH}$ value characterization}

The $\mathrm{pH}$ value of rubberwood was tested according to the Chinese standard [45]. The rubberwood was made into powder using 40-60 mesh. A combination of $3 \mathrm{~g}$ of wood powder and $30 \mathrm{~mL}$ of distilled water was mixed into a $50-\mathrm{mL}$ beaker and blended for $5 \mathrm{~min}$, then remained still for $15 \mathrm{~min}$. It was then blended again for $5 \mathrm{~min}$, and remained still for another $20 \mathrm{~min}$. Finally, the $\mathrm{pH}$ value was measured by a pH meter (Sartorius PB-10, Germany) twice.

\section{Method of 24- $h$ water absorption, mass loss ratio, and 24- $h$ swelling of wood}

The 24-h water absorption was measured according to the Chinese standard [46], and the results of different days were calculated by the following equation

$$
A=\frac{m-m_{0}}{m_{0}} \times 100[\%]
$$

where $m_{0}$ and $m$ represent the absolutely dry weight and the absorptive water weight after $24 \mathrm{~h}$, respectively. The mass loss ratio was measured according to the Chinese standard [47]. The equation of mass loss ratio is similar to that of the 24-h water absorption, but $m$ represents the weight when the rubberwood was dyed with fungi, and dried in an air dry oven at $70{ }^{\circ} \mathrm{C}$ for $12 \mathrm{~h}$.

The 24-h swelling of wood primarily consisted of radial and tangential swelling, which was calculated according to [48]. The equation for this measurement is

$$
\alpha=\frac{l-l_{0}}{l_{0}} \times 100[\%],
$$

where $l_{0}$ and $l$ represent the absolutely dry length and the absorptive water length after $24 \mathrm{~h}$, respectively.

\section{Method of compressive strength parallel to the grain}

The compressive strength parallel to the grain was measured according to [49] at the speed of $5 \mathrm{~mm} / \mathrm{s}$. The universal mechanical testing machine was provided by Jinan Nai'er Testing Machine Co., Ltd, and the equation is 


$$
\sigma_{\mathrm{w}}=\frac{P_{\max }}{b t},
$$

where $P_{\max }$ represents the failure load $(\mathrm{N})$, and $b$ and $t$ represent the length and width, respectively, of the surface in millimeters.

\section{Results and discussion SEM analysis}

Figure 1 shows SEM of vessels in undyed and dyed rubberwood. Figure 1a, b shows that there were no hyphae vessels on the cross section or radial section of the rubberwood. Figure 1c, d showed many "lines" on the cross section and radial section in the vessels of rubberwood dyed with fungi at 40 days. Figure 1e, f were the enlarged views of Fig. 1c, d. As it is illustrated in Fig. 1e, the "lines" can be identified as hyphae. Figure 1e shows that the inside of hyphae was vacant, and that the structure inside the hyphae was vacant. Figure if illustrates that the hyphae consisted of sections, and the curve shape can be attributed to the high-pressure steam in the process of sterilization [50]. Furthermore, hyphae and fibers twisted together in the cell wall, and hyphae tried to enter the pit with difficulty. Therefore,
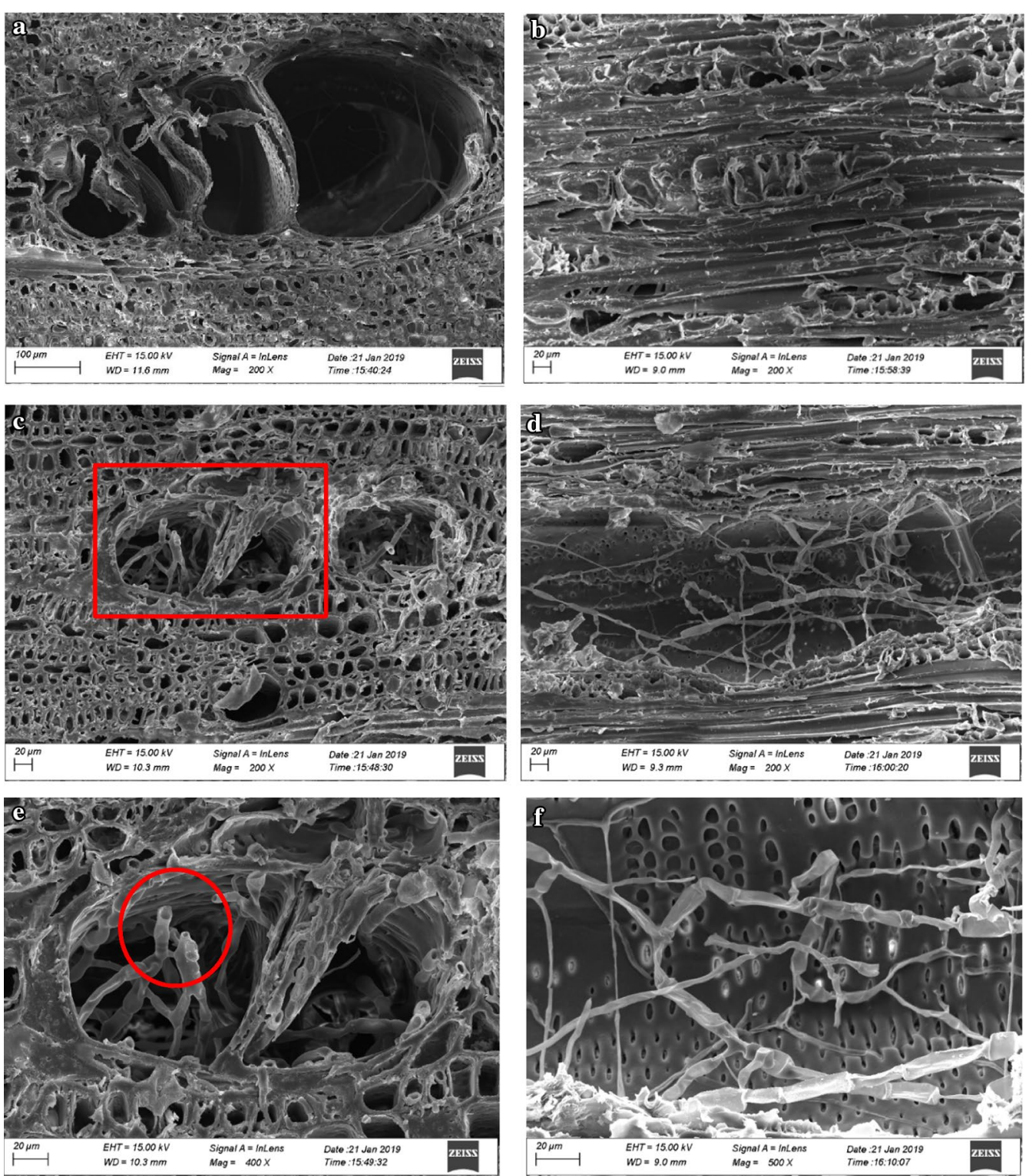

Fig. 1 SEM of vessels in undyed and dyed rubberwood. $\mathbf{a}, \mathbf{b}$ SEM of undyed rubberwood on cross section and radial section; $\mathbf{c}, \mathbf{d}$ SEM of rubberwood dyed with fungi on cross section and radial section at 40 days; $\mathbf{e}, \mathbf{f}$ SEM of detailed chart on cross section and radial section of dyed wood 
fungi can enter the vessels easily because of their large pore diameter, though it is difficult for hyphae, fungi can enter the pit or into other small pores.

Table 1 shows the EDS analysis of undyed wood, dyed wood, and fungi. The results show that the undyed wood and dyed wood primarily contained $\mathrm{C}, \mathrm{O}, \mathrm{K}$, and $\mathrm{Ca}$. Fungi mainly contained $\mathrm{C}, \mathrm{O}, \mathrm{K}$, and Na. However, although the content of the $\mathrm{C}$ element in the dyed wood decreased compared with that of the undyed wood, the content of $\mathrm{O}, \mathrm{K}$, and $\mathrm{Ca}$ increased after dyeing wood with fungi. The reason for this phenomenon could be that some structures that contained the $\mathrm{C}$ element (such as cellulose, hemicellulose, and extractives) degraded, and new structures formed when the fungi dyed the rubberwood. The XRD analysis determined the new structure to be $\mathrm{CaC}_{2} \mathrm{O}_{4}$.

\section{XRD analysis}

Figure 2 shows the XRD curves and relative crystallinity of rubberwood dyed with fungi between 0 and 40 days. The characteristic bands were measured at 15.0, 22.0, and $34.6^{\circ}$, and these values corresponded to the crystal plane diffraction bands of (101), (002), and (040) in cellulose, respectively. However, after the rubberwood was dyed with fungi, bands at $15.0^{\circ}$ noticeably increased.

Table 1 EDS analysis of undyed wood, dyed wood at $\mathbf{4 0}$ days and fungi

\begin{tabular}{llll}
\hline Element & $\begin{array}{l}\text { Undyed wood } \\
\text { (\%) }\end{array}$ & Dyed wood (\%) & Fungi (\%) \\
\hline $\mathrm{C}$ & 58.06 & 56.95 & 57.81 \\
$\mathrm{O}$ & 41.30 & 41.83 & 38.61 \\
$\mathrm{~K}$ & 0.23 & 0.32 & 2.79 \\
$\mathrm{Ca}$ & 0.41 & 0.91 & - \\
$\mathrm{Na}$ & - & - & 0.79 \\
\hline
\end{tabular}

Furthermore, several new bands appeared at 24.4, 30.0, 35.6 , and $38.2^{\circ}$ between 5 and 40 days. According to the XRD standard comparison card, the bands belonged to the structure of calcium oxalate $\left(\mathrm{CaC}_{2} \mathrm{O}_{4}\right)$, which corresponded to the results in previous studies [51]. Additionally, the results from some researchers also showed that there was a close relationship between the fungi and calcium oxalates [52-54]. EDS analysis in Table 1 also indicates that the $\mathrm{Ca}$ content in dyed wood was greater than that in undyed wood.

According to the bar chart above, relative crystallinity at 0 days was $33.03 \%$, and after fungi cultivated on the rubberwood, the relative crystallinity had a sharp increase to $37.15 \%$ at 5 days. The relative crystallinity then decreased gradually between 10 and 40 days, and was measured to be 36.17 and $35.20 \%$, respectively. However, the values of the relative crystallinity of rubberwood dyed with fungi are greater than those of the undyed wood. Although the $\mathrm{CaC}_{2} \mathrm{O}_{4}$ crystals produced on wood surface, according to the formula (1), the peaks in the formula were not the peaks in $\mathrm{CaC}_{2} \mathrm{O}_{4}$; therefore, it is difficult to explain that the production of $\mathrm{CaC}_{2} \mathrm{O}_{4}$ increased the crystallinity in different days. There may be one more possible reason that the reduction of non-crystalline or amorphous regions increased the crystallinity, and the further research is needed.

\section{FTIR analysis}

Figure 3 shows the FTIR spectra of rubberwood dyed with fungi at 0 and 40 days. In general, the rubberwood dyed with fungi at 40 days was not obviously distinct from rubberwood dyed at 0 days. However, there were some differences between the band values at 0 and 40 days. The band at $3405 \mathrm{~cm}^{-1}$ showed $-\mathrm{OH}$ in cellulose and hemicellulose, and the band value decreased between 0 and 40 days [55]. The band value at 2928
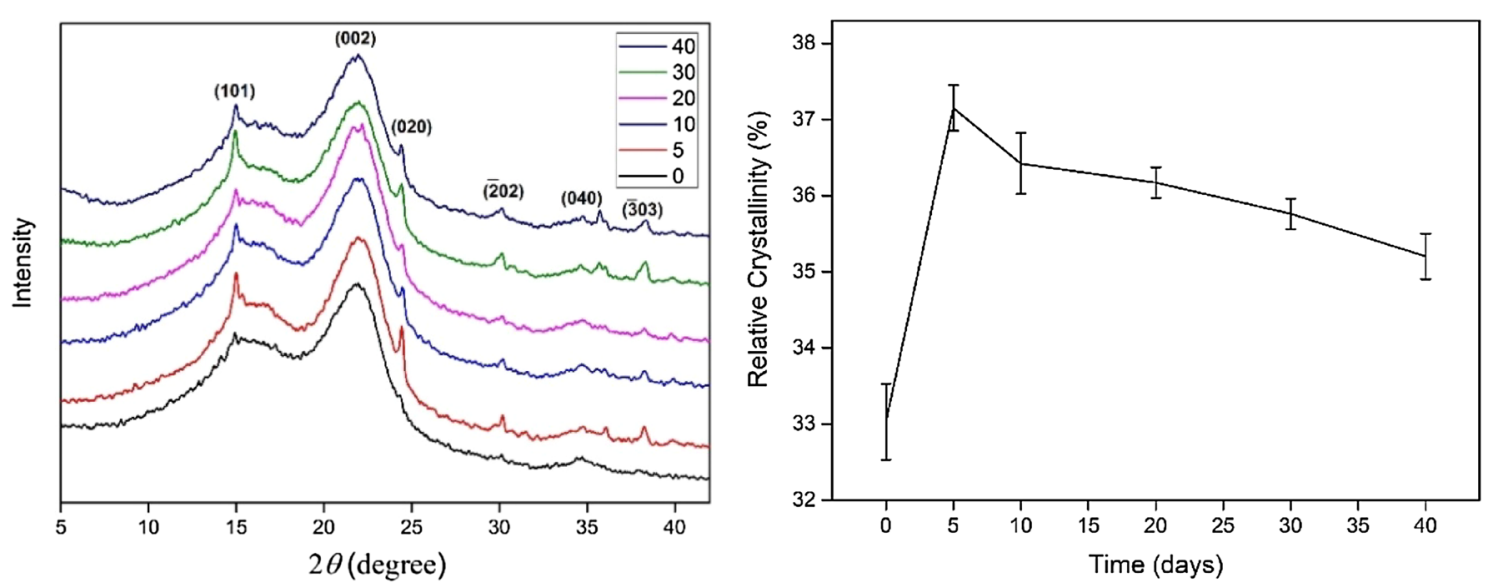

Fig. 2 XRD curves and relative crystallinity of rubberwood dyed with fungi from 0 to 40 days. The results represent the mean $\pm S D(n=3)$ 


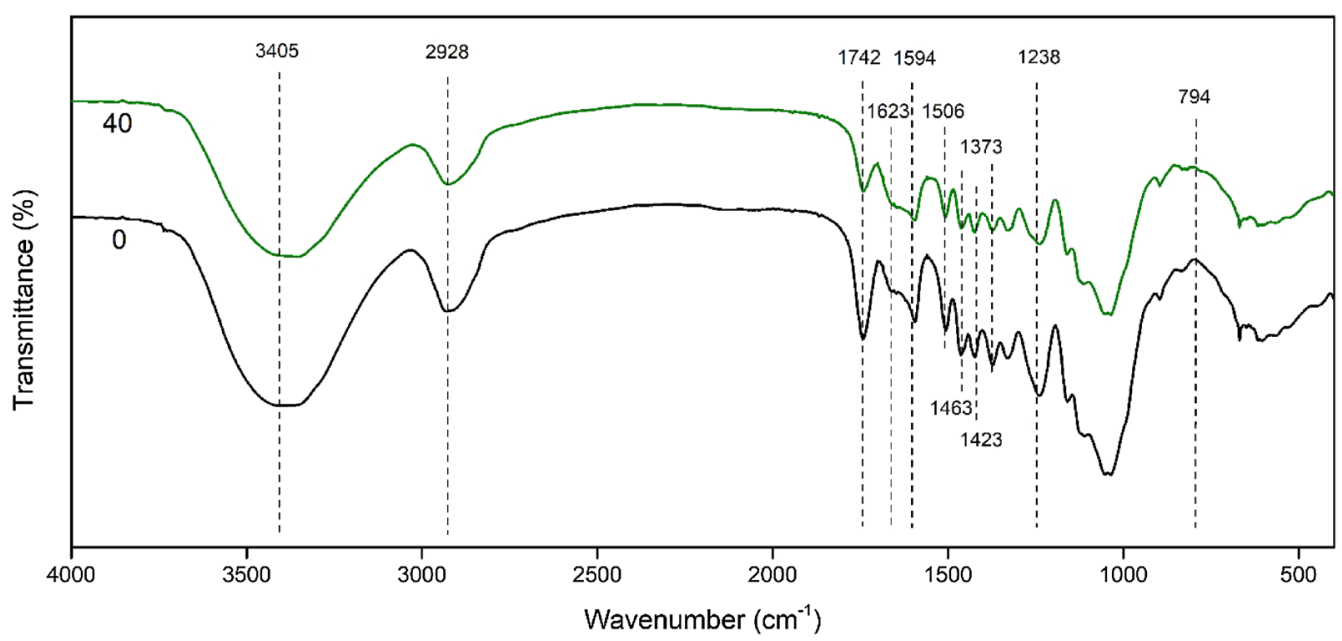

Fig. 3 FTIR spectra of rubberwood dyed with fungi at 0 and 40 days

decreased, which illustrated the vibration of $-\mathrm{CH}$ in cellulose [56]. The bands located at $1742 \mathrm{~cm}^{-1}$ corresponded to the acetyl $\left(\mathrm{CH}_{3}-\mathrm{CO}-\right)$ and $\mathrm{C}=\mathrm{O}$ stretching of the acetyl group in the hemicellulose, and the reduction tendency showed that the hemicellulose was broken $[13,57]$. The bands at 1506,1463 , and $1423 \mathrm{~cm}^{-1}$ illustrated the aromatic skeleton and $\mathrm{C}-\mathrm{H}$ in the lignin was integrated, but the decrease of bands at $1238 \mathrm{~cm}^{-1}$ indicated the decrease of $-\mathrm{OH}$ in lignin [58]. The decrease of the band at $1373 \mathrm{~cm}^{-1}$ illustrated the vibration of $-\mathrm{C}-\mathrm{H}$ in cellulose and hemicellulose. Furthermore, bands at 1623 and $794 \mathrm{~cm}^{-1}$ became broadened, which illustrated the increase of $\mathrm{COO}-$ and $\mathrm{CaC}_{2} \mathrm{O}_{4}$. Therefore, FTIR determined that the $-\mathrm{OH}$ in cellulose, hemicellulose, and lignin was slightly broken, and it is possible that the decrease of $-\mathrm{OH}$ was due to its relationship with water, which could have reacted with $-\mathrm{OH}$ when water entered the rubberwood. The $\mathrm{C}-\mathrm{H}$ in cellulose also slightly decreased.

\section{Effects of fungi pigment on wood color}

Table 2 shows the color effects of rubberwood dyed with fungi in increments between 0 and 40 days. $L^{*}, a^{*}$, and $b^{*}$ refer to brightness, red and green value, and yellow and blue value, respectively. The $L_{0}{ }^{*}, a_{0}{ }^{*}$, and $b_{0}{ }^{*}$ values of the untreated wood are 70.01, 7.71, and 17.24, respectively. The NH310 portable colorimeter showed the $\Delta L^{*}, \Delta a^{*}$, and $\Delta b^{*}$ values. With time increasing, $\Delta L^{*}$ had a positive value and gradually became smaller, which indicated that the color turned darker. The values of $\Delta a^{*}$ and $\Delta b^{*}$ were negative and became smaller, which indicated that the color turned green and blue. The difference value of $\Delta E^{*}$ gradually became smaller, which indicated that the color changed more slowly with time increasing. These values above were measured by $\mathrm{NH} 310$ portable colorimeter, and the visual effect may be a little different from measured values. Figure 4 shows that the color of the rubberwood visually. Additionally, it is evident that the color became darker and more uniform. The color at 5 days obviously showed an asymmetrical distribution on the surface of rubberwood visually, especially around the vessels, which demonstrates that fungi enter the rubberwood through the vessels. This phenomenon corresponded to the SEM analysis. The surface at 40 days was covered with pigment produced by hyphae, which distributed uniformly. Therefore, the fungi have the

Table 2 Wood color dyed with fungi in different days

\begin{tabular}{lllll}
\hline Time (days) & $\boldsymbol{\Delta} \boldsymbol{L}^{*}$ & $\boldsymbol{\Delta \boldsymbol { a } ^ { * }}$ & $\boldsymbol{\Delta} \boldsymbol{b}^{*}$ & \multicolumn{1}{c}{$\boldsymbol{E}^{\boldsymbol{*}}$} \\
\hline 0 (untreated wood) & 0 & 0 & 0 & 0 \\
5 & $-15.35 \pm 0.90$ & $-0.90 \pm 1.37$ & $-2.53 \pm 1.75$ & $15.58 \pm 1.19$ \\
10 & $-25.15 \pm 3.89$ & $0.02 \pm 1.73$ & $-2.35 \pm 1.37$ & $25.26 \pm 3.13$ \\
20 & $-34.24 \pm 2.80$ & $-2.05 \pm 0.54$ & $-4.98 \pm 0.56$ & $34.66 \pm 2.71$ \\
30 & $-39.40 \pm 2.05$ & $-1.69 \pm 0.73$ & $-6.14 \pm 1.15$ & $39.91 \pm 1.89$ \\
40 & $-40.56 \pm 1.49$ & $-0.60 \pm 0.33$ & $-4.19 \pm 0.85$ & $40.78 \pm 0.18$ \\
\hline
\end{tabular}




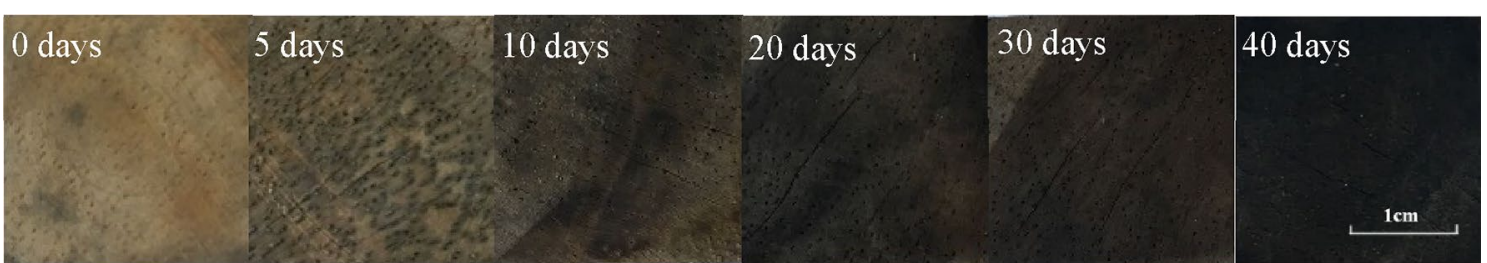

Fig. 4 The color of rubberwood from 0 to 40 days

potential to dye the surface of wood. The ANOVA and Tukey analysis showed that significant color change was achieved $(p<0.05)$ from 0 to 30 days, but no significant color change $(p>0.05)$ showed between 30 and 40 days, which corresponded to the color visually.

\section{Effects of fungi on wetting angle}

Figure 5 shows the influence of fungi on the wetting angle, which illustrates the properties of surface wettability. The chart shows that the wetting angle of undyed rubberwood was $116.9^{\circ}$; however, the wetting angle of dyed rubberwood was higher than that of the undyed wood. The contact angle of dyed wood increased from about $133^{\circ}$ at 5 days to $145^{\circ}$ at 40 days. If the fungi's hyphae were more intensive on the surface, the wetting angle would be larger until about $150^{\circ}$, at which an almost highly hydrophobic state is reached. Within $16 \mathrm{~s}$, the contact angle gradually decreases, but the contact angle decreased more dramatically between 0 and 5 days than it did between 10 and 40 days. Additionally, as time increased, the decrease rate became slower, and when the fungi fully covered the wood surface, the contact angle was nearly stable over time at $150^{\circ}$. It is possible that the fungi had a highly waterproof characteristic. Therefore, the wettability of rubberwood dyed with fungi is poorer than the wettability of undyed wood. The surface dyed with fungi is too smooth to glue with adhesives; so the dyed face is more suitable for surface decoration, coatings, adhesives and so on.

\section{Effects of fungi pigment on $\mathrm{pH}$ value of rubberwood}

Table 3 shows the $\mathrm{pH}$ value of dyed rubberwood on different days. The $\mathrm{pH}$ value of undyed rubberwood was 5.12 , and the $\mathrm{pH}$ value of dyed rubberwood increased

\section{Table 3 Fungi pigment on $\mathrm{pH}$ value of rubberwood from 0 to 40 days}

\begin{tabular}{ll}
\hline Time & pH \\
\hline 0 & 5.12 \\
5 & 5.60 \\
10 & 5.64 \\
20 & 5.98 \\
30 & 6.56 \\
40 & 6.80 \\
\hline
\end{tabular}
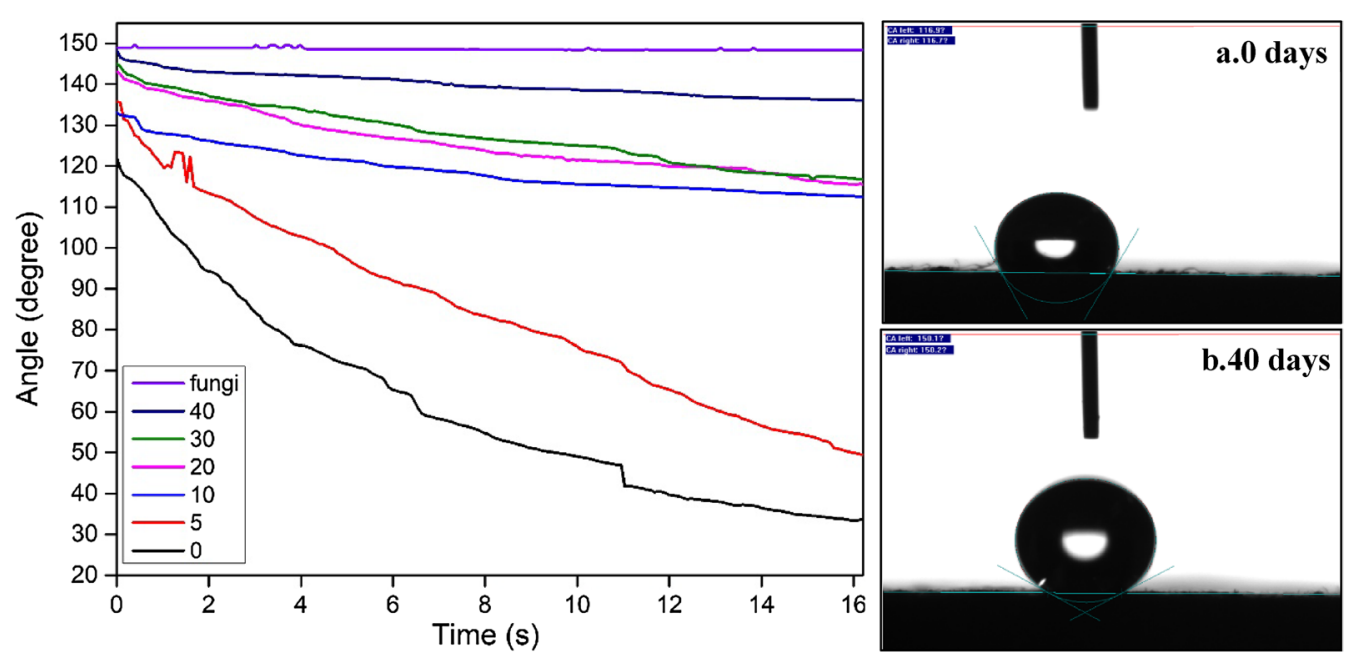

Fig. 5 Contact angle of fungi dyed rubberwood from 0 to 40 days. a Contact angle of undyed rubberwood; $\mathbf{b}$ contact angle of dyed rubberwood at 40 days 

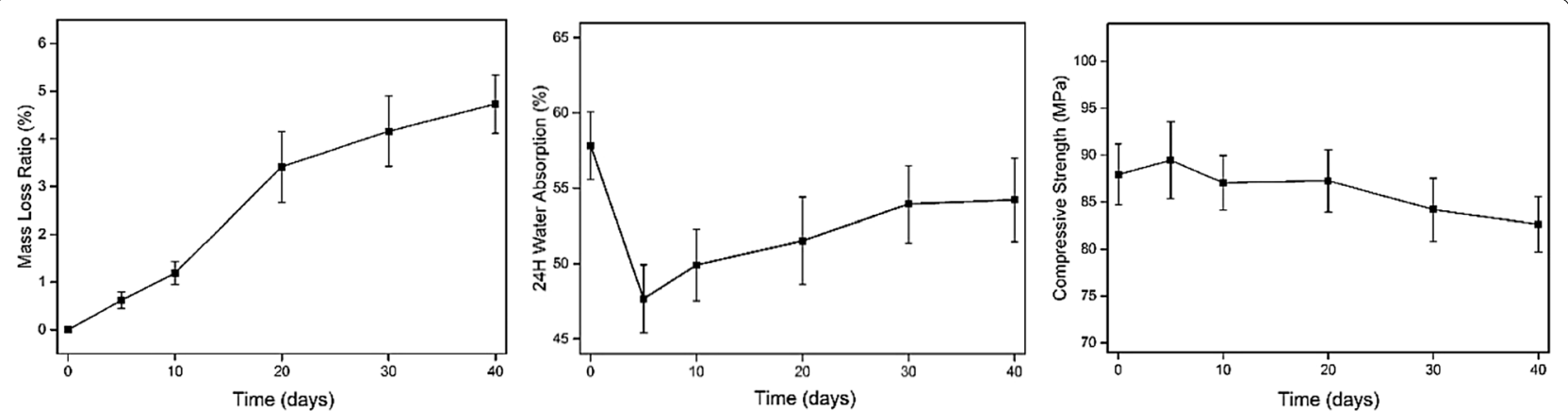

Fig. 6 Effect of fungi pigment on mass loss ratio, 24-h water absorption, and compressive strength from 0 to 40 days. The results represent the mean $\pm S D(n=5)$

gradually from 5 to 40 days until it reached 6.80 . Wood acidity primarily comes from wood extractives, uronic acid (R-) and acetyl $\left(\mathrm{CH}_{3}-\mathrm{CO}-\right)$ in hemicellulose, and $\mathrm{OH}$ in cellulose. $-\mathrm{OH}$ in uronic acid connects with $\mathrm{CH} 3-$ $\mathrm{CO}-$ to form acetic ester $\left(\mathrm{R}-\mathrm{OCOCH}_{3}\right)$, and acetic ester can react with water to form acetic acid $\left(\mathrm{CH}_{3} \mathrm{COOH}\right)$, which makes wood acidic [59]. However, FTIR analysis found a degradation of $\mathrm{CH} 3-\mathrm{CO}-$ in hemicellulose, which reduced the production of $\mathrm{CH}_{3} \mathrm{COOH}$. The extractives of rubberwood contain abundant carbohydrates and protein, which decrease significantly when fungi entered the wood; therefore, $\mathrm{pH}$ went up with time increase.

\section{Effects of fungi on mass loss ratio, 24-h water absorption and compressive strength}

Figure 6 shows the influence of fungi on mass loss ratio, 24-h water absorption, and compressive strength. Mass loss ratio increased slowly from $0(0 \%)$ to 10 days $(1.19 \%)$, and then increased more rapidly from 10 to 20 days (3.41\%). It also increased at a stable speed. $24-\mathrm{h}$ water absorption decreased sharply from 0 to 5 days, and then increased gradually from 5 to 40 days. The ANOVA analysis of the mass loss ratio and $24 \mathrm{~h}$ water absorption both showed a significantly change $(p<0.05)$ from 0 to 20 days, and changed insignificantly $(p>0.05)$ from 20 to 40 days. This is possibly because the fungi abundantly gathered in vessels and the wood surface, and received plenty of its nutrients (such as carbohydrates and water from extractives) from the rubberwood, and the vessels were blocked by hyphae, so that the oxygen and water enter the rubberwood difficultly, so 24 -h water absorption decreased. In the latter few days, fungi grew slowly due to a lack of oxygen, water, and other nutrition, and therefore the mass loss ratio increased slowly, and due to the slight degradation of cellulose and hemicellulose, the pore became larger than before, which made water absorption slightly increased.
The ANOVA analysis showed there was no obvious relationship between time and compressive strength $(p>0.05)$. However, Fig. 6 showed a slight increase at 5 days, and Humar [31] and Lum et al. [39] also drew a similar conclusion that the mechanical properties of wood improved after the wood was dyed with fungi, which illustrated mechanical properties would not reduce significantly. The FTIR analysis also showed the relationship between fungi and wood component, which illustrated there were no obviously effects on mechanical properties. What is more, the surface color analysis showed that fungi had the potential to be dyed on the rubberwood.

\section{Conclusions}

Lasiodiplodia theobromae can enter the rubberwood through vessels, and control the surface color with time increased. A highly hydrophobic surface formed on the rubberwood dyed with fungi. There was a slight degradation of cellulose and hemicellulose of wood, and the properties of rubberwood were not been affected obviously.

\section{Abbreviations}

SEM: scanning electron microscope; EDS: energy-dispersive spectrometer; XRD: X-ray diffraction; FTIR: fourier transform infrared spectrometer; L. theobromae: Lasiodiplodia theobromae; CIE: commission internationale eclairage; $\mathrm{RH}$ : relative humidity; Turkey HSD: Tukey's honestly significant difference; SPSS: statistical product and service solutions.

\section{Acknowledgements}

The authors wish to thank the Hainan State Farms Forest Industrial Group Co., Ltd and the China Forestry Culture Collection Center for supporting the experimental materials.

\section{Authors' contributions}

BZ wrote the manuscript, performed the experiment of the study and was responsible for data collection; $Z Y$ designed the experiments and analyzed the data. YZ and CQ helped performed the experiment and revised the manuscript. All authors read and approved the final manuscript. 


\section{Funding}

This work was sponsored by the Beijing Outstanding Talent Training Foundation (CN) (2017000020124G092).

\section{Availability of data and materials}

The datasets used and/or analyzed during the current study are available from the corresponding author on reasonable request.

\section{Competing interests}

The authors declare that they have no competing interests.

Received: 3 August 2019 Accepted: 21 November 2019

Published online: 30 November 2019

\section{References}

1. Zhao Y, Tan XY, Wang XQ, Liu W (2011) Dyeing properties of acetylated wood with red disperse dyes. Adv Mater Res 335-336:1061-1066

2. Bekhta P, Niemz P (2003) Effect of high temperature on the change in color, dimensional stability and mechanical properties of spruce wood. Holzforschung 57:539-546

3. Matsuo M, Umemura K, Kawai S (2014) Kinetic analysis of color changes in keyaki (Zelkova serrata) and sugi (Cryptomeria japonica) wood during heat treatment. J Wood Sci 60:12-20

4. Tuong VM, Jian L (2010) Effect of heat treatment on the change in color and dimensional stability of acacia hybrid wood. BioResources 5:1257-1267

5. Ananias RA, Ulloa J, Elustondo DM, Salinas C, Rebolledo P, Fuentes C (2012) Energy consumption in industrial drying of radiata pine. Dry Technol 30:774-779

6. Kielmann BC, Adamopoulos S, Militz H, Koch G, Mai C (2014) Modification of three hardwoods with an $\mathrm{N}$-methylol melamine compound and a metal-complex dye. Wood Sci Technol 48:123-136

7. Wang XQ, Tang RL, Zhang Y, Yu ZM, Qi CS (2016) Preparation of a novel chitosan based biopolymer dye and application in wood dyeing. Polymers 8:338-351

8. Canevari C, Delorenzi M, Invernizzi C, Licchelli M, Malagodi M, Rovetta T, Rovetta M (2016) Chemical characterization of wood samples colored with iron inks: insights into the ancient techniques of wood coloring. Wood Sci Technol 50:1057-1070

9. Christie R (2007) Environmental aspects of textile dyeing. Waste Manag 1:717-725

10. Goktas O, Duru ME, Yeniocak M (2008) Determination of the color stability of an environmentally friendly wood stain derived from laurel (Laurus nobilis L.) leaf extracts under UV exposure. For Prod J 58:77-80

11. Hernandez VA, Galleguillos F, Robinson S (2016) Fungal pigments from spalting fungi attenuating blue stain in Pinus spp. Int Biodeterior Biodegrad 107:154-157

12. de Souza-Cruz PB, Freer J, Siika-Aho M, Ferraz A (2004) Extraction and determination of enzymes produced by Ceriporiopsis subvermispora during biopulping of Pinus taeda wood chips. Enzyme Microb Technol 34:228-234

13. Pandey KK, Pitman AJ (2003) FTIR studies of the changes in wood chemistry following decay by brown-rot and white-rot fungi. Int Biodeterior Biodegrad 52:151-160

14. Jacobs K, Plaschkies K, Scheiding W, Weiß B, Melcher E, Conti E, Fojutowski A, Le Bayon I (2019) Natural durability of important European wood species against wood decay fungi. Part 2: field tests and fungal community. Int Biodeterior Biodegrad 137:118-126

15. Plaschkies K, Jacobs K, Scheiding W, Melcher E (2014) Investigations on natural durability of important European wood species against wood decay fungi. Part 1: laboratory tests. Int Biodeterior Biodegrad 90:52-56

16. Gao S, Yue X, Wang L (2019) Effect of the degree of decay on the electrical resistance of wood degraded by brown-rot fungi. Can J For Res 49:145-153

17. da Silveira MF, Gouveia FN, Moreira ACO, Oliveira JRV, Silva ASVS, Almeida GF, Costa AF (2019) Natural resistance of eight Brazilian wood species from the region Caatinga determined by an accelerated laboratory decay test against four fungi. Holzforschung 73:151-154

18. Schubert M, Volkmer T, Lehringer C, Schwarze FWMR (2011) Resistance of bioincised wood treated with wood preservatives to blue-stain and wood-decay fungi. Int Biodeterior Biodegrad 65:108-115

19. Clausen CA, Coleman RD, Yang VW (2010) Fatty acid-based formulations for wood protection against mold and sapstain. For Prod J 60:301-304

20. Yu S, Zheng S, Li K, Feng G (2015) Assessment of human health in northeast china apartments with mould growth. Procedia Eng 121:122-128

21. Robinson SC, Michaelsen H, Robinson JC (2016) Spalted wood, history, science and art of an unique material. Schiffer Publishing, Pennsylvania

22. Robinson SC, Laks PE, Richter DL, Pickens JB (2007) Evaluating loss of machinability of spalted sugar maple. For Prod J 57:33-37

23. Mallett Kl, Hiratsuka Y (1986) Nature of the "black line" produced between different biological species of the Armillaria mellea complex. Can J Bot 64:2588-2590

24. Robinson SC (2011) Destroying uniformity: using fungi to add a tactile and visual experience to functional wood. Leonardo 44:144-151

25. Hinsch EM, Robinson SC (2018) Comparing colorfastness to light of wood-staining fungal pigments and commercial dyes: an alternative light test method for color fastness. Coatings 8:189-201

26. Qin L, Guo MH, Qiu J, Liu C (2011) Study on the formation of wood zone line pattern induced by the fungi. Adv Mater Res 197-198:190-193

27. Robinson SC, Tudor D, Cooper PA (2011) Feasibility of using red pigment producing fungi to stain wood for decorative applications. Can J For Res 41:1722-1728

28. Tudor D, Robinson SC, Cooper PA (2013) The influence of $\mathrm{pH}$ on pigment formation by lignicolous fungi. Int Biodeterior Biodegrad 80:22-28

29. Tudor D, Robinson SC, Cooper PA (2012) The influence of moisture content variation on fungal pigment formation in spalted wood. AMB Express 2:69

30. Bouslimi B, Koubaa A, Bergeron Y (2014) Effects of biodegradation by brown-rot decay on selected wood properties in eastern white cedar (Thuja occidentalis L.). Int Biodeterior Biodegrad 87:87-98

31. Humar M, Vek V, Bucar B (2008) Properties of blue-stained wood. Drvna Ind 59:75-79

32. Uzunovic A, Yang DQ, Gagne P, Breuil C, Byrne A, Gignac M, Kim SH (1999) Fungi that cause sapstain in Canadian softwoods. Can J Microbiol 45:914-922

33. Teoh YP, Don MM, Ujang S (2011) Assessment of the properties, utilization, and preservation of rubberwood (Hevea brasiliensis): a case study in Malaysia. J Wood Sci 57:255-266

34. Bruce A, Stewart D, Verrall S, Wheatley RE (2003) Effect of volatiles from bacteria and yeast on the growth and pigmentation of sapstain fungi. Int Biodeterior Biodegrad 51:101-108

35. Bulcke JVD, Acker JV, Stevens M (2006) Assessment of blue-stain resistance according to the EN 152 and a reverse test method using visual and computer-aided techniques. Int Biodeterior Biodegrad 57:229-238

36. Guillén Y, Machuca A (2008) The effect of copper on the growth of wood-rotting fungi and a blue-stain fungus. World J Microbiol Biotechnol 24:31-37

37. Schubert M, Mourad S, Schwarze FWMR (2011) Automated image processing for quantification of blue-stain discolouration of Norway spruce wood. Wood Sci Technol 45:331-337

38. Mohali SR, Castro-Medina F, Úrbez-Torres JR, Gubler WD (2017) First report of Lasiodiplodia theobromae and L. venezuelensis associated with blue stain on Ficus insipida wood from the natural forest of Venezuela. For Pathol 47:1-5

39. George J (1985) Preservative treatment of bamboo, rubber wood and coconut palm. Simple methods for treating building timbers. In: Findlay WPK (ed) Preservation of timber in the tropics. Forestry Sciences, vol 17 Springer, Dordrecht

40. Lum C, Byrne T, Casilla R (2006) Mechanical properties of lodgepole pine containing beetle-transmitted blue stain. For Prod J 56:45-50

41. Krzisnik D, Lesar B, Thaler N, Humar M (2018) Performance of bark beetle damaged norway spruce wood against water and fungal decay. BioResources 13:2473-3486

42. Chow S, Obermajer A (2007) Moisture and blue stain distribution in mountain pine beetle infested lodgepole pine trees and industrial implications. Wood Sci Technol 41:3-16 
43. WS 233-2017 (2007) General biosafety standard for causative bacteria laboratories. PRC National health and family planning commission, Beijing

44. Inagaki T, Siesler HW, Mitsui K, Tsuchikawa S (2010) Difference of the crystal structure of cellulose in wood after hydrothermal and aging degradation: a NIR spectroscopy and XRD study. Biomacromolecules 11:2300-2305

45. GB/T 6043-2009 (2009) Method for determination of pH value of wood. PRC National Standard, Beijing

46. GB/T 1934 1-2009 (2009) Method for determination of the water absorption of wood. PRC National Standard, Beijing

47. GB/T 13942.1-2009 (2009) Durability of wood-Part 1: method for laboratory test of natural decay resistance. PRC National Standard, Beijing

48. ISO 4859-1982 (1982) Determination of radial and tangential swelling International Standard Organization, London

49. ISO 13061-17 (2017) Determination of ultimate stress in compression parallel to grain. International Standard Organization, London

50. Salem MZM (2016) EDX measurements and SEM examination of surface of some imported woods inoculated by three mold fungi. Measurement 86:301-309

51. Kirboga S, Oner M (2015) Inhibition of calcium oxalate crystallization by graft copolymers. Cryst Growth Des 9:2159-2167

52. Guggiari M, Bloque R, Aragno M, Verrecchia E, Job D, Junier P (2011) Experimental calcium-oxalate crystal production and dissolution by selected wood-rot fungi. Int Biodeterior Biodegrad 65:803-809

53. Gadd GM, Bahri-Esfahani J, Li Q, Rhee YJ, Wei Z, Fomina M, Liang X (2014) Oxalate production by fungi: significance in geomycology, biodeterioration and bioremediation. Fungal Biol Rev 28:36-55
54. Ray MRSRC (2009) Oxalic acid Production by Fusarium oxysporum Schlecht and Botryodiplodia theobromae Pat. Post-harvest fungal pathogens of yams (Dioscorea rotundata L.) and detoxification by Bacillus subtilis CM1 isolated from culturable cowdung microflora. Arch Phytopathol Plant Protect 42:666-675

55. Wei XY, Tao DH, Sheng XL, Zhang MH (2018) Modification of poplar wood using polyhexahydrotriazine and its effect on hygroscopicity. J Wood Chem Technol 38:214-223

56. Khalila HPSA, Ismail H, Rozman HD, Ahmad MN (2001) The effect of acetylation on interfacial shear strength between plant fibres and various matrice. Eur Polym J 37:1037-1045

57. Stefke B, Windeisen E, Schwanninger M, Hinterstoisser B (2008) Determination of the weight percentage gain and of the acetyl group content of acetylated wood by means of different infrared spectroscopic methods. Anal Chem 80:1272-1279

58. Genestar C, Palou J (2006) SEM-FTIR spectroscopic evaluation of deterioration in an historic coffered ceiling. Anal Bioanal Chem 384:987-993

59. Liu YX, Zhao GJ (2014) The chemical properties of wood. In: Wood science, 2nd edn. China Forestry Publishing House, Beijing

\section{Publisher's Note}

Springer Nature remains neutral with regard to jurisdictional claims in published maps and institutional affiliations.

\section{Submit your manuscript to a SpringerOpen ${ }^{\circ}$ journal and benefit from:}

- Convenient online submission

- Rigorous peer review

- Open access: articles freely available online

- High visibility within the field

- Retaining the copyright to your article

Submit your next manuscript at $\boldsymbol{\nabla}$ springeropen.com 